\title{
The Pandemic Discourse: A Cross-Cultural Case Study
}

\author{
Eman Abdallah Ali Khalfallah $^{1}$, Catur Keprianto ${ }^{2}$

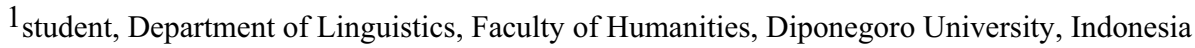 \\ 2 lecturer, Department of Linguistics, Faculty of Humanities, Diponegoro University, Indonesia
}

\begin{abstract}
The paper examines speech samples of 5 politicians, namely the presidents of Sudan, Brazil, United States, Indonesia and the British queen. Samples are taken from and specifically focused on public speech related to the events regarding the COVID-19 Pandemic. The goal of the research is to make a cross-cultural linguistic comparison based on the qualitative data. The methodology is anchored in discourse analysis of the speech samples and their interpretation. The examination has shown there are considerable individual and cultural differences between the studied subjects, which can be seen from the point of view of discourse analysis, especially in the context of power and media influence. Additionally, the paper suggests further possible points of view from which other disciplines might be used in order to build a more comprehensive understanding of the studied matter.
\end{abstract}

\section{Introduction and Theoretical Background}

Studying the relationship between language and discourse, considering a group of relationships, such as the relationship of language to power, ideology and culture, and proposing a set of theoretical levels and cognitive research, such as the origin of language, the authority of language, the powers that support it, the distinction that linguistics establishes between language, speech and discourse, forming units of discourse and internal and external linguistics, considering some of the issues raised by this relationship within a field of knowledge that tries to establish its approaches, concepts and issues on a reason that raises these relationships that are still a subject of disagreement between the linguists and sociologists about the social nature of language. Within the discourse, there are two concepts: discourse analysis and critical discourse analysis. We will employ the two concepts through this study. However, the second concept is more used in cultural and social studies. Van de Jacques believes that critical discourse analysis is not a methodology for discourse analysis in the social sciences. In fact, there is no such methodology. He adds: "Discourse analysis is not in itself a method, but rather a field of practice divided between the fields of human and social sciences. Language is a discourse and a form of social practice, with our prior knowledge of what this first definition raises in terms of linguistic problems, especially at the level of distinction between language, speech, discourse, and the relationship with society.

The analysis of the political discourse of the presidents of the republic occupies an important place in contemporary political research in various countries of the world. This importance is attributed to the centrality of the political discourse presented by the President of the Republic in any country of the country, regardless of its political system, 
authoritarian or democratic, in revealing his vision, whether for international politics or domestic politics. With regard to international politics, the importance seems to be that the President's speeches usually relate to war and peace on the one hand, and cooperation and conflict on the other hand, in the field of his country's relations with the rest of the world. Usually, the President - regardless of the political system under which he works - occupies the highest position in the field of expressing the policies of his country, although discourse analysis does not seek much beyond the lines to reach the hidden connotations or real causes as much as it seeks to deconstruct the discourse and know its systems, revealing its true goals is part of the interests of discourse analysis and critical discourse analysis.

\section{Research Methodology}

This paper analysis is based on a discourse analysis of official COVID-19 that addresses the content of five presidential candidates' speeches from the perspective of cultural linguistics, with the purpose of understanding how the authors use specific language to represent the issue of the texts' meaning. The study is data collection is from the original speech videos collected from YouTube. Linguistic comprehension promotes social engagement, and the availability of language is critical in enhancing affected individuals' responses during an epidemic crisis.

Meaning is seen as a continuous commentary in actual communication practices in cultural discourse analysis. To put it another way, when people interact with one another, they are saying things both literally about the topic at hand and culturally about who they are, how they are related, what they are doing together, and how they feel about what is going on.

\section{Analysis and Discussion}

\subsection{The Speech of Queen Elizabeth (UK, queen)}

On the 5th of April 2020, Queen Elizabeth addressed her people from Windsor Castle, A single photographer using safety gear videotaped the Queen. The message was broadcast on the BBC, but it was also extensively shared on the royal family's social media accounts, reaching people all over the world. She may have spoken to her own people, but the entire world was watching. With this phrase 'We will meet again,' queen speech titled telling her people that better days are coming She appeared wearing a simple stunning green dress with luxurious accessories. The Queen expressed her gratitude to the public for continuing to provide assistance in the homes and for welcoming those who collaborate at home. The Queen of Britain gave a public speech during the pandemic to motivate the people and to reduce the people's displeasure and doubts. Despite the fact that she is the Queen of the United Kingdom, she is simply a symbolic figure in the British system, and she cannot engage too much in the conduct of national affairs. Convention and popular will confine the shape of her rights. The Queen doesn't have many important powers, but she does have three: the right to be consulted, the ability to give advice, and the right to issue warnings. The Queen's public statement will have a significant influence on the national and international response to the epidemic.

In her speech, the Queen urged ordinary people to voluntarily segregate themselves at home and help the country fight the disease. The British people, who have long advocated for freedom, democracy, and human rights, will undoubtedly find this more convincing. The British class structure has long been a powerful point of stratification in the social, economic, and political spheres. Historically, the disparities between the working and middle classes were mostly based on people's employment (e.g. blue-collar workers vs white-collar workers). The British are rather indirect communicators; they are wary about causing disagreement and, as a result, go to great lengths to maintain politeness throughout 
discussions. This entails crafting ambiguous statements that convey their point without "rocking the boat". To avoid complaining, British people are unlikely to complain and will tolerate poor service or food. As a result, if you express your discontent in public, they may get very anxious. Personal criticism should also be delivered in an oblique manner. Otherwise, your British counterpart will become aggressive and defensive, and your criticism will be rendered ineffective. Gestures are often restrained, polite, and understated. The Queen also emphasizes the importance of persistence and solidarity in combating the disease, which is clearly at odds with Britain's long-standing commitment to freedom. The Queen highlights the need of combating the disease, stating that the calamity has caused not just grief but also financial hardship.

\subsection{The Speech of Donald Trump (USA, president)}

The speech of President Donald Trump took place on 11th March 2020 in the Oval Office of the White House. His audience was "his fellow Americans", as he addressed his listeners at the beginning of his speech to create an equal atmosphere typical for the American democratic society. Before he gets into announcing travel ban to Europe and additional measures and support programmes, in the introductory part of his speech, he takes sides in a way that can remind listeners of a war-like situation, which has been very typical for American political discourse. When Trump talks about the "unprecedented response to the coronavirus outbreak that started in China and is now spreading throughout the world" and later "sweeping travel restrictions on China" or "early reaction on China", he clearly distances himself as well as the United States form the outbreak as if it was China's fault. This can also be seen in his previous (in) famous attribute, "the Chinese virus," as he used to call it. Covid-19 has sparked a war of words between the United States and China. Both governments have blamed each other for the virus's origins and inability to confine it within their own national borders.

His speech is full of references to the greatness of America, perhaps to calm down and unite the audience. The following segments of his speech can serve as good examples: "resources to handle any threat that comes our way", "our team is the best anywhere in the world", "working closely with our federal health experts - and they are the best", "We have the best economy, the most advanced health care, and the most talented doctors, scientists and researchers anywhere in the world. We are all in this together.", "no nation is more prepared or more resilient than the United States". Trump also used personification to put the virus in the role of an enemy by saying, "the virus will not have a chance against us". In the peak or final part, he tends to put himself into the role of a "saviours" that provides the best possible advice and support available, when he four times repeatedly announces new restrictions and support programmes by starting each time with "I am (...)". He concludes his speech by referring to God; however, even here, we can see the narrow focus on the United States: "God bless you, and God bless America". Nevertheless, this phrase might be common in the cultural context of American politics. The rest of the world is mentioned rarely in his speech. This could be due to the fact it was meant for American citizens.

When it comes to extralinguistic observances, Trump adopted his usual calm and serious postures. He does not speed up in his speech, and he tends to be very confident in his voice. However, his gesticulation appears less lively than usual. The only moment when he opens his palms is in the final part when he comes from political issues into a more emotional tone saying "the virus will not have a chance against us" (...) "we are in all his together". There is a slight sign of possible nervousness as he plates with his fingers, especially in the first - more political- part when he seems unsure about the tone and level of agency to choose in his tone. The recording of the speech does not involve any other parties speaking or other audiovisual material presentation. Donald Trump is surrounded by elements of American patriotism, such as the flag on his suit as well as behind his chair. 


\subsection{The Speech of Abdalla Hamdok (Sudan, prime minister)}

Sudan announced its first new coronavirus case in Khartoum on March 13, 2020, a man who died on March 12, 2020, after visiting the United Arab Emirates in the first week of March. There had been seven confirmed cases by the end of March. At the end of March, two patients had died, one had recovered, and four cases were active. At this time, the world is facing Covid 19, and the Sudanese are facing the most difficult period of their lives. Hamdok, in a televised speech broadcast by the media of the Council of Ministers, using colloquial Arabic, started his speech to Sudanese with this phrase "Our patient, resolute, victorious people " to please the people which they overthrew the previous regime in legendry revolution and during the period of power transition, the people pay the price in blood, economic deterioration, and political confusion. It wasn't wise or sufficient for the Prime minister to inform the Sudanese how dangerous the coronavirus until death. The Sudanese revere death but do not fear it. It is something from God at the end for them. The Corona pandemic hit Sudan at a time when the country was losing a person every day. Until they've become accustomed to it, he also said that the world is going through one of the largest disasters in its contemporary history, which is the Corona disaster, and added: "We are not an exception. To let Sudanese feel it more when that even the first world realise suffers from it. He said that the recent measures might seem to restrict the citizens, but it's to protect them. Sudanese not easy to follow the rules, especially when it comes to social life. He continued, "We fully appreciate the suffering of the citizens at the boarders, and we are trying as much as possible to take measures to alleviate that suffering." Hamdok urged everyone to adhere to the Ministry of Health's guidelines as closely as possible. This pandemic, he continued, affects everything that is "beautiful and noble." Refer to the hospitality of the Sudanese and the communal ideals that are focused on being together. "We will beat this disease," he added, calling for unity and standing with "each other and joining hands."Hamdok praised all the efforts and assistance provided by the philanthropists of the people, the youth of the revolution, and all sectors and the private sector to confront the epidemic. He again encouraged "all the people" to stop participating in social activities such as weddings and funerals. "We have good and lovely habits of communication and solidarity," he continued, "but we must utterly halt these habits if we are to battle this epidemic." He claims that eliminating these habits now will help stop the coronavirus from spreading.

Sudanese people share cultural values such as a sense of social responsibility to their society and a desire to welcome guests. The concept of honour is central to the culture. People's awareness of their personal honour tends to impact their behaviour and interactions in almost all settings. Sudan is a country where As a result, implementing social distance is difficult for the state.

\subsection{The Speech of Jair Bolsonaro (Brazil, president)}

The address is delivered in Portuguese, which is Brazil's official language. For foreigners, the dominant voice may sound a little ungrateful, which may be true, but when it comes to pronunciation, Portuguese is harder than its sister language Spanish. In contrast to Spanish, where there is a strong correlation between how words are written and how they are spoken. The distinction between European Portuguese from Portugal and Brazilian Portuguese, as well as African Portuguese, is another issue with pronunciation.

Bolsonaro criticized the governors of crucial states such as Rio de Janeiro and So Paulo, who have ordered residents to stay at home and are implementing quarantines in a tetchy television appearance on Sunday night. "The people will soon realize that they were duped by these governors and a big part of the media when it comes to coronavirus," Bolsonaro remarked as his own health officials confirmed 25 deaths and 1,546 coronavirus cases in Brazil at that time. As Latin America braces for a jump in the number of deaths, Brazil's 
far-right president, Jair Bolsonaro, has accused his political adversaries and the media of purposely "tricking" citizens about the dangers of coronavirus. Bolsonaro has rejected such extreme steps, characterizing the coronavirus as "media hysteria" and referring to the condition as "the little flu."

\subsection{The Speech of Joko Widodo (Indonesia, president)}

Bahasa Indonesia is the official language of Indonesia which is the language used by President Joko Widodo. Indonesia is a collectivist country that values the group over the individual. This is reflected in society's way of life, as evidenced by this speech. President Joko Widodo began his statement with a religious greeting, "Bismillah al-Rahman alRahim," which translates to "In the name of God, the Merciful, the Beneficent." As-salamu alaykum means "Peace be upon you" in Arabic. President Widodo often uses the word we to emphasize unity, teamwork, and pride in Indonesia, as in "negara kita Indonesia" and "kuat dari kita sendiri". Widodo uses phrases that are motivational and are often repeated in order to stir citizens' enthusiasm and spirit of resistance " kita mampu melalui kesulitan ini Bersama" " Ayo kita". The Indonesian government made slogans out of short sentences with persuasive power to instil moral strength and confidence in Indonesian residents to help them get through the difficult times as "kita bisa, kita bersama " they used to repeat " One nation, one country, and one language'”.

\section{Conclusion}

This article examines the content of five presidential candidates' speeches from the standpoint of cultural linguistics, with the goal of determining how the authors express the topic of the texts' meaning through specific language. COVID-19 presents governments around the world with a once-in-a-lifetime challenge. Most countries fought for an early and severe lockdown, as well as social distances, in order to save many lives, but it came at a high cost. The disease has struck countries all over the world since its breakout in late 2019. To bolster popular sentiment and encourage it.

\section{Acknowledgement}

However, there are certain limitations in this study, such as the lack of a wider cultural linguistics aspect to analyze the texts more thoroughly. Future research is expected to look at it from a broader perspective. I am conscious of the limitations of my research, and I am aware that a far larger amount of data will be required to prove objectivity.

\section{References}

1. A. H. Abbas. Politicizing the pandemic: A schemata analysis of Covid-19 news in two selected newspapers. International Journal for the Semiotics of Law-Revue Internationale de Sémiotique Juridique 07/3, pp. 1-20. (2020)

2. L. Yu. Advances in Language and Literary Studies: Analysis of the Queen's Speech on COVID-19 from the Perspective of Transitivity. (2020)

3. D. Machin \& A. Mayr. How to do critical discourse analysis: a multimodal introduction. (2012)

4. K. Al-Mwzaiji. The Political Spin of Conviction: A Critical Discourse Analysis of the Origin of Covid-19. (2021)

5. J. Blommaert. Different approaches to intercultural communication: A critical survey. (1998)

6. Sky News Australia. (2020, April 5). We will meet again: Queen delivers "wartime spirit" address [Video]. YouTube. https://www.youtube.com/watch?v=gyy_4mBvf6o 
7. Television, C. (2020, March 11). Watch President Donald Trump's address to the nation on coronavirus pandemic [Video]. YouTube. https://www.youtube.com/watch? $v=x r P Z B T N j X \_o$

8. Sudan News Agency https://www.youtube.com/watch?v=8PCdvdoepIU (18 March, 2020)

9. Guardian News. (2020, March 25). Coronavirus crisis is a "media trick", says Brazil's Jair Bolsonaro [Video]. YouTube. https://www.youtube.com/watch? $v=s b B v u X 1 N W j E$

10. Indonesia, C. (2020, April 18). Presiden Imbau Untuk Bersatu Menghadapi Virus Corona [Video]. YouTube. https://www.youtube.com/watch?v=QUaa_EFQZcM 